\title{
The International Stroke Trial database
}

\author{
Peter AG Sandercock ${ }^{1 *}$, Maciej Niewada ${ }^{2,3}$ and Anna Członkowska ${ }^{2,3}$, for \\ the International Stroke Trial Collaborative Group
}

\section{Correction}

Following the publication of our article [1] we became aware of errors introduced in the following variables which are all dates of events variables, i.e.:

DMAJNCHD: Date of above (days elapsed from randomisation)

DSIDED: Date of above (days elapsed from randomisation)

DRSISCD: Date of above (days elapsed from randomisation)

DRSHD: Date of above (days elapsed from randomisation)

DRSUNKD: Date of above (days elapsed from randomisation)

DPED: Date of above (days elapsed from randomisation)

DALIVED: Date of above (days elapsed from randomisation)

DDEADD: Date of above (days elapsed from randomisation)

FLASTD: Date of last contact (days elapsed from randomisation)

FDEADD: Date of death (days elapsed from randomisation)

FU1_RECD: Date discharge form received (days elapsed from randomisation)

FU2_DONE: Date 6 month follow-up done (days elapsed from randomisation)

FU1_COMP: Date discharge form completed (days elapsed from randomisation).

These errors, that were introduced in the process of anonymisation, have now been corrected in the final, double checked version of the dataset, which is also available at the University of Edinburgh repository (see http://datashare.is.ed.ac.uk/handle/10283/124). Both this corrected and the erroneous version of the dataset are available to allow comparison with any previous analyses

\footnotetext{
* Correspondence: Peter.Sandercock@ed.ac.uk

'Department of Clinical Neurosciences, University of Edinburgh, Department of Clinical Neurosciences, Western General Hospital, Edinburgh EH4 2XU, UK Full list of author information is available at the end of the article
}

of the data. The corrected submission states clearly that it supersedes an earlier one.

\section{Author details}

${ }^{1}$ Department of Clinical Neurosciences, University of Edinburgh, Department of Clinical Neurosciences, Western General Hospital, Edinburgh EH4 2XU, UK. ${ }^{2}$ Department of Clinical and Experimental Pharmacology, Warsaw Medical University, Poland, Krakowskie Przedmieście 26/28, 00-927 Warsaw, Poland. ${ }^{3} 2^{\text {nd }}$ Department of Neurology, Institute of Psychiatry and Neurology, 9 Sobieskiego 02-957, Warsaw, Poland.

Received: 5 March 2012 Accepted: 6 March 2012

Published: 6 March 2012

\section{Reference}

1. Sandercock PAG, Niewada M, Członkowska A, the International Stroke Trial Collaborative Group: The International Stroke Trial database. Trial 2011, 12:101.

doi:10.1186/1745-6215-13-24

Cite this article as: Sandercock et al:: The International Stroke Trial database. Trials 2012 13:24.

Submit your next manuscript to BioMed Central and take full advantage of:

- Convenient online submission

- Thorough peer review

- No space constraints or color figure charges

- Immediate publication on acceptance

- Inclusion in PubMed, CAS, Scopus and Google Scholar

- Research which is freely available for redistribution

Submit your manuscript at www.biomedcentral.com/submit

\section{() Biomed Central}

